\title{
Evaluation of some Physicochemical Parameters and Benthic Macroinvertebrates of Ikere Gorge Reservoir in Oyo State, Nigeria
}

\section{*11ABED-NEGO OSAYANDE AIWERIOGHENE; ADEDOLAPO, ABEKE AYOADE}

\author{
${ }^{I}$ Ecology and Environmental Biology Unit, Department of Zoology, University of Ibadan, \\ Nigeria. \\ ${ }^{2}$ Hydrobiology and Fisheries Unit, Department of Zoology, University of Ibadan, Ibadan, Oyo State, Nigeria \\ *-Corresponding Author-E-mail:kenpeadobece@gmail.com \\ Phone number: $+234-8033855807$
}

\begin{abstract}
The physico-chemical parameters and benthic macroinvertebrates of Ikere Gorge Reservoir were studied to assess the impact of anthropogenic activities on this man-made lake by collecting surface water and benthic samples. Physico-chemical parameters were within the allowable limits of USEPA for fresh water bodies apart from conductivity $(0.055 \pm 0.002 \mu \mathrm{S} / \mathrm{cm})$ which was below standard. There were significant differences $(\mathrm{p}<0.05)$ in the mean values of DO, BOD, TDS, transparency, nitrate and sulphate between the sampling stations. A total of six genera (Chironomus, Melanoides, Cloeon, Bulinus, Bellamya and Hirudo) of benthic macro-invertebrates belonging to six orders (Diptera, Pelecypoda, Ephemeroptera, Heterobranchia, Caenogastropoa and Hirudinida) were recorded in the reservoir during the study. Pollution tolerant species including Melanoides tuberculata and Chironomus sp. dominated the benthic macroinvertebrates with a total number and percentage abundance of $674(56.88 \%)$ and $435(36.71 \%)$, respectively. Ikere Gorge Reservoir is relatively under stress due to dominance of indicators of pollution. ( ) JASEM
\end{abstract}

http://dx.doi.org/10.4314/jasem.v20i4.25

Keywords: Anthropogenic activities, Bioindicator, Ikere Gorge Reservoir, Melanoides tuberculata, Water quality.

All over the world, fresh water resources have been subjected to an increasing pollution load from contaminated runoff water originated from manmade activities like domestic and industrial (Banetti and Garrido, 2010). The adverse effects of human impacts on the aquatics include water - borne diseases, alteration of aquatic biota composition, eutrophication and reduction or destruction of ecosystem integrity (Sridhar et al., 1981; Egborge, 1991; Oduwole, 1997; Ekpo et al., 2012).

Biomonitoring programmes that employ indices and metrics of community structure (Udoidiong and King, 2000) had been used to assess the potential impacts or non-impacts of these alternations on the aquatic ecosystem. The richness of macroinvertebrate community composition in a water body can be used to provide an estimate of water body health (Argerich et al., 2004). The physical and chemical qualities of water and of substratum occupied by macroinvertebrates determine their occurrence and distribution (Danes and Hynes, 1980). Macroinvertebrates play an important role in aquatic community which includes mineralization, mixing of sediments and flux of oxygen into sediment, cycling of organic matter and also in assessing the quality of inland water (George et al., 2009). In Nigeria, several researchers have used the composition and distribution of macroinvertebrates to indicate the health status of water bodies ( including Arimoro, 2007; Ayoade and Olusegun, 2012; Andem et al., 2013; Okoroafor et al., 2014), however there is paucity of data on the Ikere Gorge reservoir (the only manmade lake on Ogun River).
This study is designed to evaluate the physicochemical parameters and benthic macroinvertebrates of Ikere Gorge Reservoir and this will provide information on the health status of this water body.

\section{MATERIALS AND METHODS}

Study Area: The Ikere Gorge Reservoir lies between longitudes $8^{\circ} 10^{\prime} 35^{\prime \prime} \mathrm{N}$ and latitudes $3^{\circ} 44^{\prime} 11^{\prime \prime} \mathrm{E}$. It is a major earth-fill dam in Iseyin Local Government area of Oyo State in the South west of Nigeria on the Ogun River. Reservoir capacity is 690 million $\mathrm{m}^{3}$ with surface area of $47 \mathrm{~km}^{2}$. The reservoir was planned to generate $3750 \mathrm{MW}$ of electricity, and to supply water to local communities and to Lagos and to irrigate 12,000 hectares of land. Neighboring communities depend on this reservoir for various purposes ranging from drinking water and fishing. The reservoir also receives effluents from neighboring communities in the form of domestic wastes waters from washing of clothes, sewage disposal and from non-point sources such as erosion and leaching of chemicals from nearby farm lands.

Three sampling stations were chosen for the study and human activities around these stations includes fishing, farming, washing of clothes and bathing

Determination of Physico-chemical parameters: Water samples were collected monthly (June 2014 December 2014) from the three sampling stations with plastic containers washed with nitric acid to remove any form of contaminant (Boyd, 1990). The water samples collected were then taken to the laboratory and analyzed immediately. Surface water 
temperature was determined in-situ with a mercuryin-glass thermometer and transparency was determined using a Secchi disc. Other physicochemical parameters were analysed with a Sper scientific water quality meter AF.33594. Spectophotometric screening according to APHA (2005) was used to determine nitrate, phosphate and sulphate.

Benthic Macro Invertebrates Sampling and Identification: A Van Veen Grab $(15 \mathrm{~cm} \times 15 \mathrm{~cm})$ was used to collect benthic macroinvertebrates. The sediment collected was emptied into a labelled polythene bag. The samples collected were sieved through a net with mesh size of $0.5 \mathrm{~mm}$ to eliminate the excess sediments. Organisms were sorted from the sediments and stored in vials containing $10 \%$ formalin solution. In the laboratory, organisms were identified using hand lens/microscope. Aquatic taxonomic keys (Pennak, 1978; Needham et al., 2000) were used to identify the collected specimens to species, or at least genus level.
Statistical Analysis: Duncan multiple comparison of mean was used to measure similarities of physicochemical parameters between sampling stations. Paired t-test was used to determine difference between the seasons for physico-chemical parameters and benthic macroinvertebrates. Taxa richness, diversity and evenness indices were calculated (Margalef, 1949; Shannon and Weaver, 1949; Pielou, 1966). Principal component analysis was use to analyse the interaction between the physico-chemical parameters and benthic macro invertebrates.

\section{RESULTS AND DISCUSSION}

The mean Surface Water Temperature (SWT) of the reservoir was $26.91 \pm 1.71^{\circ} \mathrm{C}$ and it did not differ significantly between stations Table 1 . The SWT of wet season months $\left(26.23 \pm 1.41^{\circ} \mathrm{C}\right)$ differed significantly from dry season months $\left(28.63 \pm 0.77^{\circ} \mathrm{C}\right)$ Table 2. The $\mathrm{P}^{\mathrm{H}}$ of the reservoir ranged from 7.66 to $9.01(8.30 \pm 0.61)$ Table 1 . The dry season months $\mathrm{P}^{\mathrm{H}}$ $(8.94 \pm 0.93)$ was significantly higher than wet season $(8.04 \pm 0.51)$.

Table 1: Spatial Variation in the Physico-chemical Parameters of Ikere Gorge Reservoir

\begin{tabular}{|c|c|c|c|c|c|c|c|}
\hline & & & & & & & \\
\hline Parameters & 1 & 2 & 3 & Mean \pm SD & Range & US EPA & NESREA \\
\hline Air Temperature $\left({ }^{\circ} \mathrm{C}\right)$ & $24.50^{\mathrm{a}}$ & $24.70^{\mathrm{a}}$ & $24.70^{\mathrm{a}}$ & $24.60 \pm 0.15$ & $24.50-24.70$ & $20-33$ & $30-32$ \\
\hline Surface Water Temperature $\left({ }^{\circ} \mathrm{C}\right)$ & $27.00^{\mathrm{a}}$ & $26.70^{\mathrm{a}}$ & $27.10^{\mathrm{a}}$ & $26.90 \pm 0.40$ & $26.70-27.10$ & $20-33$ & $30-32$ \\
\hline $\mathrm{P}^{\mathrm{H}}$ & $8.30^{\mathrm{a}}$ & $8.33^{\mathrm{a}}$ & $8.31^{\mathrm{a}}$ & $8.30 \pm 0.14$ & $8.30-8.33$ & $6.5-8.5$ & $6.5-9.0$ \\
\hline Dissolved Oxygen (mg/L) & $5.59^{\mathrm{a}}$ & $5.36^{\mathrm{b}}$ & $5.13^{\mathrm{c}}$ & $5.36 \pm 0.29$ & $5.13-5.59$ & $\geq 4$ & $\geq 5$ \\
\hline Biochemical Oxygen Demand(mg/L) & $1.23^{\mathrm{a}}$ & $0.96^{\mathrm{b}}$ & $0.67^{\mathrm{c}}$ & $0.95 \pm 0.30$ & $0.67-1.23$ & $\leq 6.0$ & $\leq 10$ \\
\hline Conductivity $(\mu \mathrm{S} / \mathrm{cm})$ & $0.056^{\mathrm{a}}$ & $0.054^{\mathrm{a}}$ & $0.054^{\mathrm{a}}$ & $0.055 \pm 0.002$ & $0.054-0.056$ & 240 & $\leq 1000$ \\
\hline Total Dissolved Solid (mg/L) & $37.30^{\mathrm{a}}$ & $35.60^{b}$ & $36.10^{\mathrm{ab}}$ & $36.3 \pm 1.15$ & $35.60-37.30$ & 200 & $\leq 200$ \\
\hline Transparency (m) & $2.63^{\mathrm{a}}$ & $1.75^{\mathrm{b}}$ & $1.66^{\mathrm{c}}$ & $2.01 \pm 0.55$ & $1.66-2.63$ & - & - \\
\hline Nitrate $(\mathrm{mg} / \mathrm{L})$ & $0.29^{\mathrm{a}}$ & $0.49^{b}$ & $0.28^{\mathrm{a}}$ & $0.35 \pm 0.12$ & $0.28-0.49$ & 4.0 & - \\
\hline Sulphate $(\mathrm{mg} / \mathrm{L})$ & $0.09^{\mathrm{a}}$ & $0.139^{\mathrm{b}}$ & $0.07^{\mathrm{a}}$ & $0.10 \pm 0.036$ & $0.09-0.139$ & & \\
\hline Phosphate (mg/L) & $0.16^{\mathrm{a}}$ & $0.15^{\mathrm{a}}$ & $0.18^{\mathrm{a}}$ & $0.16 \pm 0.024$ & $0.15-0.18$ & 3.5 & - \\
\hline
\end{tabular}

The same alphabet in the same row is not significantly different $(\mathrm{P}<0.05)$; USEPA: United State Environmental Protection Agency; NESREA: National Environmental Safety, Regulatory and Enforcement Agency

Table 2: Seasonal Variation in mean Physico-chemical characteristics (minimum and maximum in parentheses) of Ikere Gorge Reservoir, Southwestern Nigeria

\begin{tabular}{|c|c|c|c|c|}
\hline Parameters & Rainy season months & Dry season months & t-test & Probability \\
\hline Surface Water Temperature $\left({ }^{\circ} \mathrm{C}\right)$ & $26.23 \pm 0.36(24-29)$ & $28.63 \pm 0.32(27.3-29.3)$ & $* 0.001$ & $\mathrm{p}<0.05$ \\
\hline $\mathrm{P}^{\mathrm{H}}$ & $8.04 \pm 0.13(7.43-8.89)$ & $8.94 \pm 0.038(8.82-9.1)$ & $* 0.000$ & $\mathrm{p}<0.05$ \\
\hline Dissolved Oxygen (mg/L) & $5.47 \pm 0.27(3.7-6.8)$ & $5.07 \pm 0.194(4.5-5.7)$ & 0.370 & $\mathrm{p}<0.05$ \\
\hline Biochemical Oxygen Demand(mg/L) & $0.90 \pm 0.09(0.4-1.9)$ & $1.08 \pm 0.09(0.8-1.4)$ & 0.277 & $\mathrm{p}<0.05$ \\
\hline Conductivity $(\mu \mathrm{S} / \mathrm{cm})$ & $0.05 \pm 0.00(0.05-0.06)$ & $0.06 \pm 0.001(0.055-0.059)$ & $* 0.004$ & $\mathrm{p}<0.05$ \\
\hline Total Dissolved Solid (mg/L) & $36.07 \pm 0.36$ & $37.00 \pm 0.45$ & 0.159 & $\mathrm{p}<0.05$ \\
\hline Transparency (m) & $2.01 \pm 0.144$ & $2.02 \pm 0.19$ & 0.962 & $\mathrm{p}<0.05$ \\
\hline Nitrate $(\mathrm{mg} / \mathrm{L})$ & $0.24 \pm 0.04$ & $0.64 \pm 0.06$ & $* 0.000$ & $\mathrm{p}<0.05$ \\
\hline Sulphate $(\mathrm{mg} / \mathrm{L})$ & $0.09 \pm 0.014$ & $0.14 \pm 0.01$ & $* 0.026$ & $\mathrm{p}<0.05$ \\
\hline Phosphate (mg/L) & $0.16 \pm 0.05$ & $0.17 \pm 0.10$ & 0.341 & $\mathrm{p}<0.05$ \\
\hline
\end{tabular}

*: significantly different at $\mathbf{p}<0.05$

The mean DO was $5.36 \pm 0.92 \mathrm{mg} \mathrm{L}^{-1}$ ( 4.9 to $\left.6.63 \mathrm{mg} / \mathrm{L}\right)$ and it differed significantly between the stations. The mean BOD of Ikere Gorge Reservoir was $0.95 \pm 0.20 \mathrm{mg} \mathrm{L}^{-1}$ and it differed significantly between stations. Conductivity of the reservoir ranged from 0.053 to $0.056 \mu \mathrm{S} / \mathrm{cm}\left(0.055 \pm 0.001 \mu \mathrm{S} \mathrm{cm}^{-1}\right)$. The mean transparency $(2.01 \pm 0.55 \mathrm{~m})$ of the reservoir differed significantly between stations. Nitrate concentration of Ikere Gorge Reservoir ranged from $0.100 \mathrm{mg} \mathrm{L}^{-1}$ to $0.702 \mathrm{mg} \mathrm{L}^{-1}$ concentration was significantly lower than dry season $\left(0.35 \pm 0.23 \mathrm{mg} \mathrm{L}^{-1}\right)$. The rainy season month concentration (Table 2$)$. 
Sulphate concentration ranged from $0.054 \mathrm{mg} \mathrm{L}^{-1}$ to $0.146 \mathrm{mg} \mathrm{L}^{-1}\left(0.10 \pm 0.04 \mathrm{mg} \mathrm{L}^{-1}\right)$ with the dry season months concentration being significantly higher than rainy season months. The monthly variation of phosphate ranged from $0.149 \mathrm{mg} \mathrm{l}^{-1}$ to $0.168 \mathrm{mg} \mathrm{L}^{-1}$ $\left(0.16 \pm 0.01 \mathrm{mgL}^{-1}\right)$.

The mean surface water temperature, dissolved oxygen and $\mathrm{pH}$ were within the permissible limits of United State Environmental Protection Agency (USEPA) and National Environmental Standards and Regulatory Enforcement Agency (NESREA) standard for rivers/lakes. The mean temperature and $\mathrm{pH}$ values for the three sampling stations of Ikere gorge Reservoir studied were comparable with previous studies done on some selected water bodies in the south-western Nigeria (Etim and Adie, 2012). From the findings of the present study, the mean dissolved oxygen of the three sampling stations was not in accordance with studies of Yakub and Ugwumba (2009), who reported low DO in lower River Ogun caused by organic-rich abattoir effluents.

The BOD values of the three sampling stations of Ikere Gorge Reservoir were within the permissible limits of USEPA $\left(\leq 6.0 \mathrm{mgl}^{-1}\right)$ and NESREA $(\leq 10)$ standards. The low mean BOD reported in this study can be attributed to the high flow rate of the reservoir and in such a way it is able to recover from organic load from external sources. Water with biochemical oxygen demand less than $4 \mathrm{mgl}^{-1}$ are termed reasonably clean and unpolluted, while water with level greater than $10 \mathrm{mgl}^{-1}$ are considered polluted since they contain large amount of degradable organic materials (Ohimain et al., 2008) . Conductivity was low and this can be attributed to the fact that the substratum of the reservoir comprises mainly of granite (Igneous rock) and granite is composed of more inert materials that do not ionize (dissolve into organic component) when washed into the reservoir. Boyd (1978) stated that natural water normally has conductivity ranges from 20-1500 $\mu \mathrm{Scm}^{-1}$. The result obtained in this study is contrary to a range of $13-31 \mu \mathrm{Scm}^{-1}$ in upper Ogun River observed by Adebisi, 1989.

The phosphate concentration of the Ikere gorge reservior was low as compared to the standard guidelines (USEPA, 2008). The result revealed that the nutrient load of Ikere Gorge Reservoir is low. Nitrate is a form of nitrogen and a vital nutrient for growth, reproduction, and the survival of organisms. High nitrate levels $\left(>1 \mathrm{mg} \mathrm{L}^{-1}\right)$ are not good for aquatic life (Johnson et al., 2009).

Six benthic macroinvertebrates belonging to three phyla (Arthropoda, Mollusca and Annelida), three classes (Insecta, Gastropoda and Clitellata), six orders (Diptera, Pelecypoda, Ephemeroptera, Heterobranchia, Caenogastropoda and Hirudinida) and six genera (Chironomus, Melanoides, Cloeon, Bulinus, Bellamya and Hirudo) were recorded from Ikere Gorge Reservoir (Table 3).

Table 3: Checklist of Benthic Macro-invertebrates in Ikere Gorge Dam Reservoir, Iseyin

\begin{tabular}{llllll}
\hline Phylum & Class & Order & Family & Genus & Species \\
\hline Arthropoda & Insecta & Diptera & Chironomidae & Chironomus & \\
Arthropoda & Insecta & Ephemeroptera & Ephemeridae & Cloeon & $\begin{array}{l}\text { Dipterum } \\
\text { Mollusca }\end{array}$ \\
Gastropoda & Pelecypoda & Thiaridae & Melanoides & tubercuta \\
Mollusca & Gastropoda & Heterobranchia & Planorbidae & Bulinus & \\
Mollusca & Gastropoda & Caenogastropoda & Viviparidae & Bellamya & Unicolor \\
Annelida & Clitellata & Hirudinida & Hirudinidae & Hirudo & \\
\hline
\end{tabular}

The wet season months recorded higher distribution of benthic macro invertebrates than the dry season months. Melanoides tuberculata and Chironomus spp were well distributed between seasons (Table 4)

Table 4: Seasonal Distribution of Benthic Macroinvertebrates of Ikere Gorge Reservoir.

\begin{tabular}{|cccccc|}
\hline \multicolumn{5}{|c|}{ Number of Benthic Macroinvertebrates (Percentage of abundance) } \\
\hline Season & $\begin{array}{c}\text { Chironomus } \\
\text { spp }\end{array}$ & $\begin{array}{c}\text { Melanoides } \\
\text { tuberculata }\end{array}$ & $\begin{array}{c}\text { May fly Larvae } \\
\text { (Cloeon } \\
\text { dipterum) }\end{array}$ & $\begin{array}{c}\text { Bulinus sp } \\
\text { Leech (Hirudo } \\
\text { species) }\end{array}$ & $\begin{array}{c}\text { Bellamya } \\
\text { unicolor }\end{array}$ \\
\hline Wet & $262(38.53 \%)$ & $374(55 \%)$ & $4(0.59 \%)$ & $25(3.68 \%)$ & $1(0.15 \%)$ \\
\hline Dry & $173(34.02 \%)$ & $300(59.06 \%)$ & $5(0.98 \%)$ & $22(4.33 \%)$ & $2(0.39 \%)$ \\
\hline
\end{tabular}

Station $3(57.55 \%)$ recorded the highest abundance of benthic macroinvertebrates and station $1(2.11 \%)$ recorded the least. The benthic macroinvertebrates with the highest percentage abundance was Melanoides tuberculata $(56.88 \%)>$ Chironomus spp. $(36.71 \%)>$ Bulinus sp. $(3.97 \%)>$ Bellamya unicolor $(1.43 \%)>$ Cloeon dipterum $(0.76 \%)$ with Hirudo $(0.25 \%)$ having the least ( Table 5). 
Table 5: Percentage Abundance of Benthic Macroinvertebrates in Different Sampling Stations of Ikere Gorge Reservoir.

\begin{tabular}{|c|c|c|c|c|c|c|c|}
\hline \multicolumn{8}{|c|}{ Number of Benthic Macroinvertebrates (Percentage abundance) } \\
\hline $\begin{array}{l}\text { Sampling } \\
\text { Stations }\end{array}$ & Chironomus sp & $\begin{array}{l}\text { Melanoides } \\
\text { Tuberculata }\end{array}$ & $\begin{array}{l}\text { May fly Larvae } \\
\text { (Cloeon } \\
\text { dipterum) }\end{array}$ & Bulinus sp & $\begin{array}{l}\text { Leech } \\
\text { (Hirudo species) }\end{array}$ & $\begin{array}{l}\text { Bellamya } \\
\text { unicolor }\end{array}$ & Total \\
\hline Station 1 & $5(20 \%)$ & 0 & 0 & $20(80 \%)$ & 0 & 0 & $25(2.1 \%)$ \\
\hline Station 2 & $173(36.19 \%)$ & $285(59.62 \%)$ & $1(0.21 \%)$ & $14(2.93 \%)$ & 0 & $5(1.05 \%)$ & $478(40.3 \%)$ \\
\hline Station 3 & $257(37.68 \%)$ & $389(57.04 \%)$ & $8(1.17 \%)$ & $13(1.91 \%)$ & $3(0.44 \%)$ & $12(1.76 \%)$ & $682(57.6 \%)$ \\
\hline Total & $435(37 \%)$ & $674(57 \%)$ & $9(0.76 \%)$ & $47(3.97 \%)$ & $3(0.25 \%)$ & $17(1.43 \%)$ & 1185 \\
\hline
\end{tabular}

Spatial variation occurred in the diversity indices with Station 3 being highest in terms of species richness, followed by Station 2 and then Station 1 for the Margalef's and Shannon-Weiner indices. Station 1 had the highest species evenness 0.73 , while species in stations 2 and 3 were equally even (Table 6)

Table 6: Spatial variation in diversity indices of Benthic

\begin{tabular}{cccc} 
Macro-invertebrates of Ikere Gorge Reservoir, Iseyin Nigeria \\
\cline { 2 - 5 } Stations & $\begin{array}{l}\text { Margalef's } \\
\text { Index }\end{array}$ & $\begin{array}{c}\text { Shannon- } \\
\text { Wiener }\end{array}$ & Evenness \\
\hline Station 1 & 1.43 & 0.22 & 0.73 \\
Station 2 & 1.49 & 0.36 & 0.52 \\
Station 3 & 1.76 & 0.40 & 0.52 \\
\hline
\end{tabular}

From the Principal component analysis (Fig. 1) showing the interaction between physico-chemical parameters and benthic macroinvertebrates, it was observed that the distribution and abundance of some benthic macroinvertebrates such as Mayfly nymph (Cloeon dipterum), Bulinus sp., Leech (Hirudo species), and Bellamya unicolor were determined by changes in some physico-chemical parameters such as $\mathrm{pH}, \mathrm{DO}, \mathrm{BOD}$, conductivity, transparency, nitrate, sulphate and phosphate. The abundance and distribution of Chironomus sp. and Melanoides tuberculata were independent of any physicochemical parameter. Surface water temperature and TDS did not affect the distribution and abundance of any benthic macroinvertebrates.

From the present study, the low number of benthic macroinvertebrates encountered could be due to some ecological imbalance arising from alterations of some important factors (including water quality, immediate substrates for occupation and food availability) governing the abundance and distribution of the benthic communities(Andem et al., 2012). Similar results were obtained by Ogbeibu and Egborge(1995) in water bodies in the Okomu forest reserve (sanctuary) in southern Nigeria and they stated that high biodiversity is expected in ecosystems devoid of significant anthropogenic impacts. The occurrence and dominance of pollution tolerant species (Melanoides tuberculata and Chironomus larvae) in the study area suggests deterioration of water quality. Chironomus larvae are known to thrive in polluted environment probably due to possession of hemoglobin a pigment that transport and store dissolved oxygen (Tyokumbur et al., 2002). The presence of these indicator species suggests organic pollution from anthropogenic source. 


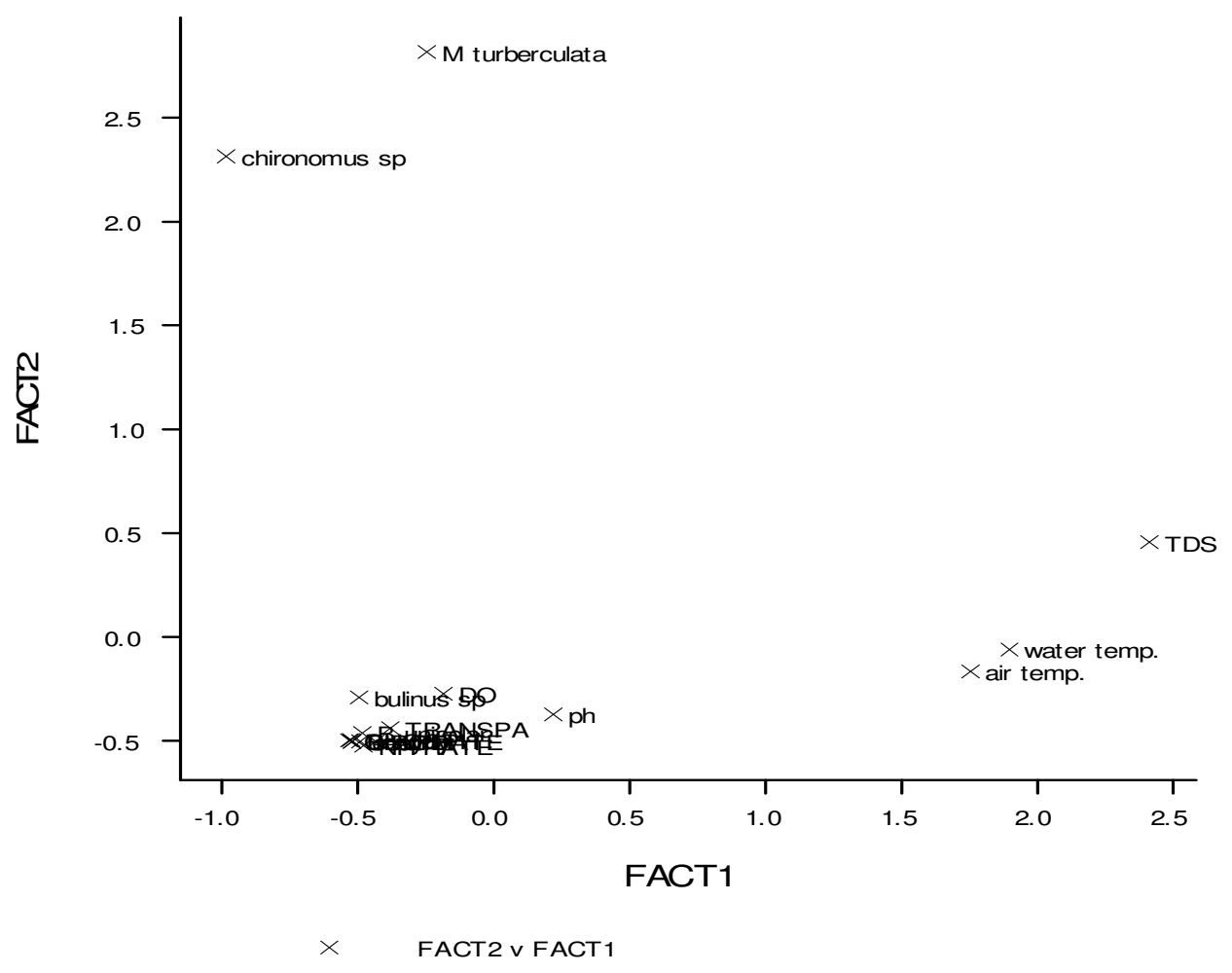

Fig 1: Principal component analysis (PCA) showing the interaction between Physico-chemical parameters and benthic macroinvertebrates of Ikere gorge Reservoir

Conclusion: The physico-chemical parameters of Ikere Gorge Reservoir were within the allowable limits for fresh water bodies apart from conductivity which was below standard. The dominant benthic macroinvertebrates fauna of the reservoir recorded were pollution-tolerant species. The low number of benthic macroinvertebrates of Ikere Gorge Reservoir and the dominant species (Melanoides tuberculata and Chironomus sp.) being pollution tolerant suggest that the reservoir is relatively under stress. It is relatively polluted with organic pollutants from anthropogenic sources such as the surrounding communities and waterfront dwellers releasing raw human excreta, detergents, and wastewater and cleaning agents from the communities. Therefore regular assessment of the water quality is advised as to checkmate the increasing pollution trend.

\section{REFERENCES}

Adebisi, AA (1989). Planktonic and benthic organisms in some ponds on the Olupona fish farms, Olupona, Oyo State, Nigeria. A Report Prepared for Agro Team S. R. I. Ibadan, Nigeria.

Ajao, EA; Fagade, SO (2002). The benthic macrofauna of Lagos Lagoon. The Zoologist $2: 1$ -15 .
American Public Health Association (APHA) (2005). Standard Methods for the Examination of Water and Wastewater Analysis, 21st Edition, American Water Works Association/Water Environment Federation, Washington D.C.

Andem, BA; Okorafor Eyo, KA; Ekpo, PB (2012). Ecological Impact Assessment and Limnological Characterization in the Intertidal Region of Calabar River Using Benthic Macroinvertebrates as Bioindicator Organisms. Int. J.Fishe. Aqua. Studies 1(2): 8-14

Argerich A; Puig MA; Pupilli, E ( 2004). Effects of floods of different magnitude on the macroinvertebrate communities of Matarranya stream (Ebro river basin, NE Spain). Limnetica 23 (3/4): 283-294.

Arimoro, FO; Ikomi, RB; Efemuna, E (2007). Macroinvertebrate Community Patterns and diversity in relation to water quality status of River Ase, Niger Delta, Nigeria. J. Fishe. Aqua. Sci.2 (5): $337-344$

Ayoade, AA; and Olusegun, OA (2012): Impacts of effluents on the limnology of a tropical river, southwestern Nigeria. J. Appl. Sci. Environ. Manage. 16 (2): 201-207 
Banetti, CJ; Garrido, J ( 2010). The influence of stream habitat and water quality on water beetles assemblages in two rivers in northwest Spain. Vie et milieu 60 (1): 53-63.

Boyd, CE. 1978. Water quality in ponds for Aquaculture. Auburn University, Agricultural. Experimental Station, Auburn: Alabama.

Chapman, D (1996). Water Quality Assessments - A Guide to Use of Biota, Sediments and Water in Environmental Monitoring - Second Edition.E\&FN Spon, an imprint of Chapman \& Hall.

Danes, KW; Hynes, HBN (1980). Some effects of agricultural land use on stream insect communities. Environmental Pollution Series A 22: $19-28$

Egborge, ABM (1991). Industrialization and heavy metal pollution in Warri River. Inaugural lecture delivered at the University of Benin, Nigeria. 32p.

Esenowo IK; Ugwumba AAA(2010). Composition and abundance of macrobenthos in Majidun River Ikorordu Lagos state Nigeria. Res. J. Biol. Sci. 5(8): 556-560.

Ekpo, IE; Chude, LA; Onuoha, GC ( 2012). The use of multivariate analysis for characterisation and classification of Ikpa River, Nigeria. Elix. Agric.49: 9799-9807.

Etim, EU; Adie GU (2012). Assessment of Qualities of Surface Water, Sediments and Aquatic Fish from Selected Major Rivers in South-Western Nigeria. Res. J. Environ. Earth Sci.4 (12): 10451051 .

Fagade, SO; Adebisi, AA; Kolo, RJ; Elemi, BF; Adeosun, AA; Ja'afru, A. (1993).

Urbanisation and degradation of aquatic resources. The Ibadan experience. Natural Conference on Conservation of Aquatic Resources. May 11 14, 1992. Calabar, Nigeria.

George , ADI; Abowei, JFN ; Daka, ER (2009). Benthic MacroInvertebrate Fauna and Physicochemical Parameters in Okpoka Creek Sediments, Niger Delta. Nig. Internat. J. Anim.Vet. Adv.1(2): 59 - 65

James, JH; Heinrich, C; Smith, J ( 2002). The Performance of Performance Standards. $J$. Hum. Resour. 37 (4):778-811.
Johnson, KS; Sakamoto, CM; Coletti, LJ. (2009). An improved algorithm for the computation of nitrate concentrations in seawater using an in situ ultraviolet spectrophotometer methods. Limnol. Oceanogra. 7: 132-140

Lawson EO (2011). Physico-chemical parameters and heavy metal contents of water from the mangrove swamps of Lagos Lagoon, Lagos, Nigeria. idosi publications. Adv. Biol. Res.5

(1): $8-21$

Margalef, DI. (1949). Diversidad de species en las comunidales naturals. Publication institute biological application. Barcelona 9: 5-27.

Mason, JR; Cummings, JL.; Otis DL; Heisterberg JF(1991). Evaluation of dimethyl and methyl anthranilate as a Canada goose repellent on grass. Wildlife Soc. Bull.19:184-190.

Mustapha, MK ( 2008). Assessment of the Water Quality of Oyun Reservoir, Offa, Nigeria,using selected Physico-Chemical Parameters. Turk. J. Fishe. Aqua. Sci. 8: 309-319

Needham, JG; Westfall MJ; May ML. (2000). Dragonflies of North America. Revised edition. Scientific Publishers inc., Gaineville: Florida.

Oduwole, GA (1997). Indices of pollution in Ogunpa and Ona Rivers, Ibadan, Nigeria: Physicochemical, trace metal and plankton studies. Unpublished Ph. D Thesis. University of Ibadan, Nigeria. 236p.

Ogbeibu, AE ; Egborge, AB (1995). Hydrobiological studies of water bodies in the Okomu Forest Reserve (Sanctuary) in southern Nigeria. 1. Distribution and diversity of the invertebrate fauna. Trop. Freshwater Biol.4:1-27.

Ohimain, EI; Imoobe, TOT; Bawo, DDS (2008). Changes in water physico-chemistry following the dredging of an oil well access canal in the Niger Delta. Wor. J. Agric. Sci. 4(6): $752-758$

Okorafor , KA; James, ES; Udoh, AD( 2014). Assessment of Macro-invertebrates and Physicochemical Parameters of the Lower Qua Iboe River, Akwa Ibom State, Nigeria. ARPN J. Sci. Tech.4: $667-675$.

Pennack, RW (1978). Freshwater invertebrates of the United States, 2nd Edition, John Wiley \& Sons, New York 
Pielou, EC (1966). The measurement of diversity in different type of biological collections. J. Theore. Biol. 13:131-144.

Ravera, S; Massari, G; Genovesi V (2006). Phytoclimatic characterization of lichen habitat in central Italy. Nova Hedwigia 82(1-2):143-165.

Shannon, CE; Weaver, W. (1949). The Mathematical theory of communication. University of Illinois, Press-Urbana.

Sridhar, MK; Oluwande, PA; Okubadejo, AO ( 1981). Health hazards and pollution from open drains in a Nigerian city. Ambio 10(1): 29-33.

Tyokumbur, ET; Okorie, ET; Ugwumba, OA. (2002). Limnological assessment of the effluent on macroinvertebrate fauna in Awba stream and
Reservoir, Ibadan, Nigeria. The Zoologist 1: 59 62.

Udoidiong, OM; King, RP (2000). Ichthyofaunal assemblages of some Nigerian Rainforest streams. J. Aqua. Sci. 15: 1-8

United State Environmental Protection Agency (2004). Biological indicators of Watershed health. Available at http://www.epa.gov.

United States Environmental Protection Agency (2008). Drinking Water Health Advisory for Boron, EPA 822-R-08-013.

Yakub, AS; Ugwumba, AAA (2009). Effects of Abattoir effluents on some physicochemical parameters and fresh water prawns (Macrobrachium) of Lower Ogun River, Western Nigeria.

Nig. J. Fishe. 6 (2): 93-101. 